Original Research Article

\title{
Prescription pattern of analgesics in outpatient department in a tertiary care teaching hospital in North India
}

\author{
Rajeev Mishra, S. S. Keshari*
}

Department of Pharmacology, TSM Medical College and Hospital, Lucknow, Uttar Pradesh, India

Received: 19 July 2017 Accepted: 22 August 2017

\section{*Correspondence to:}

Dr. S. S. Keshari,

Email: drsskeshari@gmail.com

Copyright: (C) the author(s), publisher and licensee Medip Academy. This is an openaccess article distributed under the terms of the Creative Commons Attribution NonCommercial License, which permits unrestricted noncommercial use, distribution, and reproduction in any medium, provided the original work is properly cited.

\begin{abstract}
Background: Pain is an unpleasant sensory and emotional experience which is associated with actual or potential tissue damage or described in such terms. NSAIDs are most commonly prescribed drugs for the treatment of pain and inflammation and is most commonly prescribed drug around the world. NSAIDs are also most commonly used drug over the counter. Present study was done to evaluate the prescription pattern of analgesics and to assess the rational use of conventional non-steroidal anti-inflammatory drugs (NSAIDs), selective cyclooxygenase-2 (COX-2) inhibitors, and opioid analgesics.

Methods: Present study was Cross sectional study, done at outdoor department of Orthopaedics at T.S. Misra Medical College and Hospital, Lucknow during January 2017 to April 2017 in a pre-designed and pre-tested proforma. Both male and female patients, above the age of 18 years, who were willing to participate in this study were enrolled. Samples of 253 prescriptions were screened randomly and verbal informed consent was taken. Data were analysed using MS Excel 2007 and summarized as counts and percentages. Statistical analysis was not done as it was a descriptive study.

Results: Most commonly prescribed analgesics were non-selective NSAIDs followed by selective COX-2 inhibitors. Most commonly prescribed FDCs combination was diclofenac with paracetamol.

Conclusions: This study shows that diclofenac is the most frequently prescribed analgesic in orthopaedics OPD at this hospital. The extensive use of irrational FDCs must be curtailed. We observed in present study that most of the prescriptions were rational. But there are scopes for improvement by introducing appropriate educational intervention for rational prescribing.
\end{abstract}

Keywords: Analgesics, NSAIDs, PPIs, Prescription pattern, Selective COX-2 inhibitors

\section{INTRODUCTION}

Pain is an unpleasant sensory and emotional experience which is associated with actual or potential tissue damage or described in such terms. ${ }^{1,2}$ Aim of prescribing pattern studies is to provide the feedback to the physician and to insure awareness about rational use of medicines. ${ }^{3}$ NSAIDs are most commonly prescribed drugs for the treatment of pain and inflammation and is most commonly prescribed drug around the world. NSAIDs are also most commonly used drug over the counter. These drugs act by interfering the cyclooxygenase (COX) pathway. The COX enzyme exists in two isoforms; COX-1 and COX- 2. The
COX-1 is constitutive that regulates physiological functions such as mucus production the stomach as well as platelet formation whereas COX-2, is mainly involved in the synthesis of prostaglandins during the inflammatory response. ${ }^{4}$ Major limitations of classical NSAIDs are gastrointestinal toxicity and it is due to inhibition of COX1 in gastrointestinal tract. Selective COX-2 inhibitors are GI friendly drug. ${ }^{5}$ There are some recent evidences of cardiovascular adverse events with the use of COX-2 selective inhibitors that created a sense of insecurity not only among prescribers but also among consumers. ${ }^{6}$ Besides NSAIDs, Tramadol is commonly prescribed opioid analgesic in orthopaedics outpatient department (OPD). Tramadol is equally efficacious as morphine or 
meperidine in the treatment of mild to moderate pain. Opioid analgesics were previously used very frequently to suppress pain but their use is restricted now for selective cases only because of undesirable side effects.

\section{METHODS}

Present study was Cross sectional study, done at outdoor department of Orthopaedics at T.S. Misra Medical College and Hospital, Lucknow during January 2017 to April 2017 in a pre-designed and pre-tested proforma. Both male and female patients, above the age of 18 years, who were willing to participate in this study were enrolled. Samples of 253 prescriptions were screened randomly and verbal informed consent was taken. We adopted the inclusion criteria for patients who received analgesics in orthopaedics OPD during study period irrespective of diagnosis, and treatment. 25 prescriptions were excluded on the basis of life style modification and exercise. On the basis of inclusion and exclusion criteria, 228 participants were selected and results are based upon the data obtained from these participants. Data were analysed using MS Excel 2007 and summarized as counts and percentages. Statistical analysis was not done as it was a descriptive study.

\section{RESULTS}

In present study, we observed that there were 593 drugs prescribed. Out of which, 527 drugs were oral drugs while 66 were topical drugs. In present study, we observed that the average number of drug per prescription was 4.72. In present study, we observed that the most commonly prescribed analgesics were non-selective NSAIDs (65.4\%) followed by selective COX-2 inhibitors (12.6\%) (Table 1).

Table 1: Prescribed drug category $(\mathrm{N}=593)$.

\begin{tabular}{|lll|}
\hline Drug category & No. & $\%$ \\
\hline Non-selective NSAIDs & 388 & 65.4 \\
\hline COX Selective NSAIDs & 75 & 12.6 \\
\hline Opioid analgesics & 36 & 6.1 \\
\hline Proton Pump Inhibitors & 45 & 7.6 \\
\hline $\mathrm{H}_{2}$ antihistaminic blockers & 27 & 4.5 \\
\hline Muscle relaxants & 22 & 3.7 \\
\hline
\end{tabular}

NSAIDs: Non-steroidal anti-inflammatory drugs, PPIs: Proton pump inhibitors

In present study, we observed that the most commonly prescribed non-selective COX inhibitor was diclofenac (22.8\%) followed by aceclofenac (7.2\%). Most commonly prescribed preferential COX-2 inhibitor was etodolac (10.4\%). Among selective COX-2 inhibitors; etoricoxib $(9.4 \%)$ was the only prescribed drug. Most commonly prescribed opioid analgesics was tramadol $(6.1 \%)$. In present study, we observed that gastroprotective agents like PPIs and $\mathrm{H}_{2}$ antihistaminic blockers were coadministered with NSAIDs. Most commonly prescribed PPI was pantoprazole (6.6\%) (Table 2).
Table 2: Class of drugs prescribed $(\mathrm{N}=593)$.

\begin{tabular}{|lll|}
\hline Name of the drug & No. & $\%$ \\
\hline Diclofenac & 135 & 22.8 \\
\hline Etodolac & 62 & 10.4 \\
\hline Etoricoxib & 56 & 9.4 \\
\hline Piroxicam & 54 & 9.1 \\
\hline Tramadol & 36 & 6.1 \\
\hline Aceclofenac & 43 & 7.2 \\
\hline Ibuprofen & 41 & 6.9 \\
\hline Pantoprazole & 39 & 6.6 \\
\hline Tizanidine & 35 & 5.9 \\
\hline Ranitidine & 32 & 5.4 \\
\hline Paracetamol & 29 & 4.9 \\
\hline Chlorzoxazone & 25 & 4.2 \\
\hline Rabeprazole & 6 & 1.0 \\
\hline
\end{tabular}

In present study, we observed that most commonly prescribed FDCs combination was diclofenac with paracetamol $(27.8 \%)$ followed by a combination of diclofenac, paracetamol with chlorzoxazone (12.9\%). (Table 3).

Table 3: Details of fixed dose combinations $(\mathrm{N}=227)$.

\begin{tabular}{|lcl|}
\hline Fixed dose combination & No. & $\%$ \\
\hline Combination of NSAIDs with NSAIDs & & \\
\hline Diclofenac+Paracetamol & 67 & 29.5 \\
\hline Ibuprofen+Paracetamol & 19 & 8.4 \\
\hline Piroxicam+Paracetamol & 18 & 7.9 \\
\hline Aceclofenac+Paracetamol & 32 & 14.1 \\
\hline Etoricoxib+Diclofenac & 09 & 4.0 \\
\hline Combination of NSAIDs +Muscle relaxants \\
\hline Diclofenac+Paracetamol+Chlorzoxazone & 25 & 11.0 \\
\hline Diclofenac+Tizanidine & 14 & 6.2 \\
\hline Diclofenac+Chlorzoxazone & 11 & 4.8 \\
\hline Aceclofenac+Chlorzoxazone & 8 & 3.5 \\
\hline Combination of NSAIDs+Opioids & \\
\hline Paracetamol+Tramadol & 24 & 10.6 \\
\hline
\end{tabular}

FDC: Fixed drug combination, NSAIDs: Non-steroidal antiinflammatory drugs

\section{DISCUSSION}

NSAIDs are most commonly prescribed analgesic agent for the management of pain and inflammation. Gastrointestinal toxicity is the major limitation of NSAIDs in their clinical use. That is why NSAIDs are frequently co-prescribed with gastroprotective agents. ${ }^{8}$ In the present study, we observed that diclofenac $(22.8 \%)$ was most commonly prescribed NSAIDs. This was in accordance to the previous study done by Bhasker et al. ${ }^{9}$ Selective COX2 inhibitors were also frequently prescribed analgesic but use of selective NSAIDs have declined over the years due to their cardiovascular toxicity. ${ }^{10,11}$ In the present study, it was observed that NSAIDs were most frequently prescribed with PPIs (7.6\%) followed by $\mathrm{H}_{2}$ receptor blockers $(4.5 \%)$. Main reason of their use was NSAIDs 
associated peptic ulcer and gastrointestinal bleeding. ${ }^{12} \mathrm{~A}$ previous study revealed that the proton pump inhibitors were used as the anti-ulcer agents of choice. ${ }^{13}$ Among opioid analgesics, tramadol was the most commonly prescribed drug either alone or in combination with NSAIDs. This was in accordance with the previous study done by Bhaskar et al. ${ }^{9}$ We also observed in present study that there was frequent use of FDC of analgesics. Previous studies revealed that combination of two NSAIDs is irrational and does not improves the efficacy of treatment. Irrational FDCs increase the chances of adverse drug effects. ${ }^{14}$ Combining opioid analgesics with NSAID is more rational, as the two drugs act on different pathways. ${ }^{15}$ We observed in this study that most of the analgesics were prescribed rationally. WHO has recommended the use of ATC classification/DDD system as a tool for presenting drug utilization research to improve the quality of drug use. $^{16}$

The average number of drugs per prescription is an important parameter in prescription audit. Polypharmacy and irrational prescription may result in adverse effects. In present study, we observed that the average number of drug per prescription was 4.72 . This was in accordance to previous studies in which three or more drugs were prescribed per prescription. ${ }^{17}$ The reference value for average number of drugs in WHO guidelines on rational use of drugs per prescriptions 1.6-1.8. ${ }^{18}$

\section{CONCLUSION}

This study shows that diclofenac is the most frequently prescribed analgesic in orthopaedics OPD at this hospital. The extensive use of irrational FDCs must be curtailed. We observed in present study that most of the prescriptions were rational. But there are scopes for improvement by introducing appropriate educational intervention for rational prescribing. There is need for adherence to analgesic treatment guidelines and continuing education for clinicians. This effort may improve the quality of health care.

Funding: No funding sources Conflict of interest: None declared

Ethical approval: The study was approved by the Institutional Ethics Committee

\section{REFERENCES}

1. Monfared H, Sferra JJ, Mekhail N. The medical management of chronic pain. Foot Ankle Clin. 2004;9:373-403.

2. Tabish A, Jha RK, Rathod AM, Rathod RM, Gupta KK. Prescribing trend of analgesics in a tertiary health care setup of rural Vidarbha. Res J Pharm Biol Chem Sci. 2012;3:566-71.

3. Shankar PR, Pai R, Dubey AK, Upadhyay DK. Prescribing patterns in the orthopaedics outpatient department in a teaching hospital in Pokhara, western
Nepal. Kathmandu Univ Med J (KUMJ). 2007;5(1):16-21.

4. Vane JR. Inhibition of prostaglandin synthesis as a mechanism of action for aspirin-like drugs. Nat New Biol. 1971;231(25):232-5.

5. Graumlich JF. Preventing gastrointestinal complications of NSAIDs. Risk factors, recent advances, and latest strategies. Postgrad Med. 2001;109(5):117-20,123.

6. Tandon VR. Painkillers and cardiovascular toxicity. Health Line Fam Med J. 2006;4(4):33-4.

7. Brunton LL, Chabner BA, Knollman BC. Goodman \& Gilman's The Pharmacological Basis of Therapeutics. $12^{\text {th }}$ Edition. New York: McGraw-Hill Companies Inc.; 2011:501,508,992.

8. Muraraiah S, Rajarathna K, Vishwanath M, Ramaswamy A, Kamath SD, Seshu S, et al. Evaluation of WHO prescribing indicators among orthopaedic inpatients at a tertiary care hospital. J Chem Pharm Res. 2014;6:278-80.

9. Bhaskar R, Veena DR, Padma L, Kumar PA, Moosaraza S. Prescription pattern of analgesics in orthopaedics outpatient department at a tertiary care hospital. Int J Basic Clin Pharmacol. 2015;4:250-3.

10. Tandon VR. Pain killers and cardiovascular toxicity. Health Line Fam Med J. 2006;4(4):33-4.

11. Mukherjee D, Nissen SE, Topol EJ. Risk of Cardiovascular events associated with selective COX2 inhibitors. JAMA. 2001;286(8):954-9.

12. Lapane KL, Spooner JJ, Mucha L, Straus WL. Effect of nonsteroidal anti-inflammatory drug use on the rate of gastrointestinal hospitalizations among people living in long term care. J Am Geriatr Soc, 2001;49(5):577-84.

13. Rahman MS, Zinnat AB, Samad MK. Prescribing pattern of nonsteroidal anti-inflammatory drugs at outpatient departments of teaching hospital. Bangladesh J Pharmacol. 2007;2:1-6.

14. Gautam CS, Saha L. Fixed dose drug combinations (FDCs): rational or irrational: a view point. Br J Clin Pharmacol. 2008;65(5):795-6.

15. Gautam CS, Saha L. Fixed dose drug combinations (FDCs): rational or irrational: a view point. Br J Clin Pharmacol. 2008;65(5):795-6.

16. WHO Collaborating Centre for Drug Statistics Methodology, Guidelines for ATC classification and DDD assignment 2013. Oslo, 2012 (Last accessed on 15 July 2017).

17. WHO Medicines Situation. Available at: http://apps.who.int/medicinedocs/en/d/Js6160e/10.

18. WHO. How to investigate drug use in health facilities: selected drug indicators, action program on essential drugs (DAP), Geneva, 1993. Available at: http://apps.who.int/medicinedocs/en/d/Js2289e/.

Cite this article as: Mishra R, Keshari SS.

Prescription pattern of analgesics in outpatient department in a tertiary care teaching hospital in North India. Int J Basic Clin Pharmacol 2017;6:2372-4. 